\title{
A system dynamics approach for assessing SMEs’ competitiveness
}

\author{
Esteban Lafuente \\ Department of Management, Universitat Politècnica de Catalunya (Barcelona Tech) \\ EPSEB, Av. Gregorio Marañón, 44-50, E-08028 Barcelona, Spain \\ E-mail: esteban.lafuente@upc.edu \\ László Szerb \\ Faculty of Business and Economics, University of Pécs \\ Pécs Rákóczi út 80. 7622-Hungary \\ E-mail: szerb@ktk.pte.hu \\ András Rideg \\ Faculty of Business and Economics, University of Pécs \\ Pécs Rákóczi út 80. 7622-Hungary \\ E-mail: ridega@ktk.pte.hu
}

\begin{abstract}
Acknowledgements: For their ideas and insightful comments that helped us to improve the paper the authors are grateful to conference participants at the 2014 Via Futuri International Conference (University of Pécs, Hungary), at the 19th Interdisciplinary Conference on Entrepreneurship and Innovation (University of Kassel, Germany, 2015), and at the 30th RENT Conference (University of Antwerp, Belgium, 2016). This research was supported by the European Union (TÁMOP project: No. 4.2.2 A-11/1/KONV-2012-0058). Esteban Lafuente acknowledges financial support from the Spanish Ministry of Economy, Industry and Competitiveness (grant: ECO2017-86305-C4-2-R).
\end{abstract}

WORKING PAPER VERSION: MAY 2020

\section{PLEASE CITE AS FOLLOWS:}

Lafuente, E., Szerb, L., Rideg, A. (2020). A system dynamics approach for assessing SMEs' competitiveness. Journal of Small Business and Enterprise Development, in press, doi: https://doi.org/10.1108/JSBED-06-2019-0204 


\title{
A system dynamics approach for assessing SMEs’ competitiveness
}

\begin{abstract}
:
Purpose: The analysis of the interconnectedness between resources and capabilities, and the way businesses use them as competitive weapons is a central element of the strategic management literature. Finding the appropriate configuration of competitive pillars is particularly relevant for resource-constrained small businesses. Drawing on the resourcebased view and the configuration theory, this study evaluates the effect of both competitiveness and the configuration of the competitiveness system on performance.

Design/methodology/approach: An index methodology based on the configuration theory was used to compute the competitiveness index on a unique sample of 625 Hungarian small and medium-sized firms. The study hypotheses were tested via regression analysis.

Findings: Results show that the impact of competitiveness-enhancing strategies is conditional on the configuration of the system of competencies. Low-competitive businesses benefit more from investments in the weakest competitive pillar, while strategies oriented to improve more than one competitive pillar yield higher competitiveness improvements among highcompetitive businesses. Our findings also indicate that competitiveness positively impacts performance, and that the exploitation of competitive strengths leads to superior results among high-competitive businesses.

Originality/value: By employing an index methodology, our analysis contributes to unveil how competitiveness impact business performance. The proposed analysis has value for scholars and strategy makers by showing how the configuration of the business' competitive system-in terms of competitive strengths and weaknesses - conditions the generally positive impact of competitiveness enhancing actions linked to the acquisition or development of resources and capabilities.
\end{abstract}

Keywords: Competitiveness, resource-based view, system dynamics, SMEs, Hungary JEL codes: L25, M2

\section{Introduction}

A central proposition of the resource-based view of the firm (RBV) is that businesses acquire or develop resources and capabilities that interact with the existing ones in order to create competencies as they pursue competitiveness and, ultimately, superior performance (Barney, 1991; 2001; Prahalad and Hamel, 1990). Competitiveness is linked to a sustained competitive advantage, and is often conceptualized as the capacity of businesses for efficiently orchestrating their resources and capabilities with the objective to create valueadding competencies (Barney and Mackey, 2005; Grant, 1991).

Nevertheless, businesses do not realize the generally positive effects of investments in resources of capabilities at the same intensity (see e.g., Newbert, 2007). This is particularly 
relevant for small and medium-sized firms (SMEs) as their more reduced access to relevant resources limits their capacity to adopt competitive-enhancing strategies (Man et al., 2002).

Studies rooted in the RBV frame emphasize that businesses with superior structures maintain their competitive edge on the basis that their resources and capabilities are not easily duplicable or surpassable (Barney, 2001; Nason and Wiklund, 2018). Therefore, the heterogeneous distribution of resources and capabilities among competing firms contributes to explain both the differences in business endowments and the dissimilar ability of firms to create a resource-based competitive advantage.

The analysis of how the associations between resources and capabilities condition business competitiveness is the focus of this study. This paper employs a managerial tool to evaluate SMEs' competitiveness. Specifically, our measure reflects the multidimensional nature of competitiveness by connecting the resource-based view and the configuration theory in a model that considers the role of resources and capabilities in shaping competitiveness.

Competitiveness is an attractive concept characterized by its long-term orientation, controllability and dynamism (Barney, 2001; Man et al., 2002). RBV literature has devoted considerable efforts to assess competitiveness using aggregate estimates that capture the contribution of different resources and capabilities to competitiveness (e.g., Fernhaber and Patel, 2012; Hult et al., 2007). Despite the rigorous efforts, underlying these studies are methodological approaches that ignore the different interactions that might exist between the variables that form business competitiveness.

To address these issues, we propose a competitiveness index based on a system dynamics model that incorporates into the analysis system-level constraints between the analyzed resources and capabilities. Building on RBV theory postulates, competitiveness is defined as the mutually dependent bundle of resources and capabilities that allow the creation or development of valuable competencies (Barney, 2001; Prahalad and Hamel, 1990). The proposed competitiveness measure is formed by 46 variables grouped in ten competitive pillars that represent different resources and capabilities.

Furthermore, we show how the proposed managerial tool functions by analyzing the responsiveness of the competitiveness index to changes in competitive pillars at the businessand industry-level. In the second stage analysis we examine the relationship between the competitiveness index and employment growth. The empirical application considers a sample of 625 Hungarian SMEs operating in manufacturing, retailing, and professional services sectors during the period 2010-2013. This setting provides an opportunity to assess how 
different competencies contribute to business competitiveness in contexts where the interactions between resources and capabilities are complex and heterogeneous.

This article extends the existing literature on competitiveness in two main ways. First, by drawing on the RBV and the configuration theory frames, our comprehensive competitiveness measure employs an index methodology that allows multiple interactions between the different pillars that shape competitiveness. Competitiveness analyses based on metrics that incorporate the interconnectedness of resources and capabilities is a gap in the literature that our paper contributes to fill (see, e.g., Lafuente et al., 2019; Siggelkow, 2011). Second, we show how an analysis based on our competitiveness index helps unveil the effects of competitiveness-enhancing actions in businesses with different system configurations. By connecting the RBV and the configuration theory we contribute to further understand the drivers of competitiveness, which is critical for managerial decision-making processes.

Also, the contribution of this study extends to the small business management literature. Small businesses show significant particularities in terms of organization, resource allocation, managerial styles, strategic choices and the way of competition (Man et al., 2002; Porter 1998). By examining competitiveness from a systemic perspective, SME managers might be in a better position to balance strategic investments with actions that contribute to exploit their business' resources and capabilities. Instead of studying the individual contribution of competitive factors, we evaluate how different strategic configurations—competitive strengths, competitive weaknesses or a harmonized competitive system-impact employment growth. Thus, this paper contributes to increase the stock of knowledge dealing with SME's competitiveness (e.g., Lafuente et al., 2019; Nason and Wiklund, 2018; Sirmon et al., 2010).

\section{The resource-based view of the firm and business competitiveness}

\subsection{The resource-based theory of the firm}

Organizations seek to gain and develop bundles of knowledge and skills_-capabilitieswhich enable them to employ their internal resources more effectively (e.g., capital, labor, and materials). Resource-based view (RBV) theorists propose that the associations resulting from connecting resources and capabilities_labeled competencies-contribute to enhance business competitiveness and subsequent performance (Prahalad and Hamel, 1990; Wernerfelt, 1984). The heterogeneous distribution of resources and capabilities among firms explains both the differences in business endowments and the dissimilar ability of businesses to create a resource-based competitive advantage (Barney, 1991). Businesses with superior systems and structures achieve higher performance and maintain their competitive edge on the basis that 
their resources and capabilities are not easily duplicable or surpassable (Barney and Mackey, 2005). Research rooted in the RBV is extensive and has mostly evaluated two fundamental assertions of this theory (Crook et al., 2008; Newbert, 2007): (1) that some resources and capabilities have the potential to enable businesses to implement value-creating strategies, and (2) that such resources and capabilities can be a source of competitive advantage when they possess attributes that make their imitation costly.

Perhaps because of the difficulties of measuring competitiveness (Ketchen et al., 2007), most empirical studies have sought to evaluate the individual contribution of different resources or capabilities to performance (Crook et al., 2008; Newbert, 2007). Underlying this approach is the assumption that competitiveness is evident in organizations whose resources and capabilities are positively correlated to performance. Organizations are a bundle of resources and capabilities and these ingredients do not work in isolation and, as Newbert (2008, p. 751) points out, “it is unlikely that a firm's competitive position is solely attributable to any one specific resource or capability.” Instead, businesses pursuing a competitive advantage must demonstrate the ability to exploit their resources and capabilities in such a way that their full potential is realized (Grant, 1991; Sirmon et al., 2011).

Competitiveness is a complex construct that should be evaluated from a holistic approach to better understand how organizations “do business” (Barney, 2001). The core of our analysis is to match resources and capabilities with the creation of value-adding competencies, while acknowledging the multidimensionality of competitiveness as well as the complementarities that exist between the business' resources and capabilities.

\subsection{The drivers of competitiveness: Competitive strengths and weaknesses}

Competitiveness is a multidimensional construct characterized by its long-term orientation, controllability and dynamism, and is often conceptualized as the capacity of the firm to amalgamate its resources and capabilities seeking to create value-adding competencies (Barney and Mackey, 2005; Grant, 1991).

Studies rooted in the RBV show a great deal of variation in the resources and capabilities used to operationalize competitiveness. For example, variables related to the product/service and business operations are "usual suspects" in competitiveness analyses (Douglas and Ryman, 2003; Fernhaber and Patel, 2012; Hult et al., 2007). Prior research has also analyzed the role of competencies related to human capital-e.g., accumulated knowledge, knowledge acquisition, and technical skills_-(Aral and Weill, 2007; Julien and Ramangalahy, 2003), internationalization (Belderbos and Sleuwaegen, 2005), networking (Kingsley and Malecki 
2004), marketing (O’Cass and Weerawardena 2010), and the business' strategic orientation (Hansen et al., 2013). Also, recent technology advances have allowed the development of ITbased competencies - e.g., use of ITs, database management and e-commerce deepeningwhich have drawn scholarly attention (Aral and Weill, 2007; Tippins and Sohi, 2003).

Among studies measuring competitiveness via factor analysis or structural equation models, a positive relationship is reported between competitiveness and various performance metrics, including: 1) accounting ratios such as return on assets or return on sales (Aral and Weill, 2007; Douglas and Ryman, 2003), 2) export-oriented variables (Julien and Ramangalahy, 2003), 3) performance constructs computed by factor analysis using financial and managerial variables (O’Cass and Weerawardena, 2010; Tippins and Sohi, 2003), 4) growth in sales, employment and market share (Fernhaber and Patel, 2012), and 5) shareholder's value (Hansen et al., 2013).

Consistent with postulates of the RBV frame (Barney, 1991; Prahalad and Hamel, 1990), these studies support the notion that competitiveness is a multidimensional construct linked to resources and capabilities, and that competitiveness is positively correlated with performance. Existing studies also show that the value of resources and capabilities for improving competitiveness is fully realized only when they are effectively capitalized (Sirmon and Hitt, 2009). This argument has fueled research rooted in the RBV which has mostly hypothesized that firms capable of acquiring and exploiting valuable competencies will achieve superior performance for two reasons (Crook et al., 2008; Sirmon et al., 2010). First, increased competitive strengths allow the business to react to changing market conditions in unique ways (Douglas and Ryman, 2003). Second, the complementarities between strong competitive factors multiply the value that each can create for consumers, and allow businesses to improve the price/quality relationship of their products/services (Sirmon et al., 2010).

At the business level, competitiveness is not only affected by the exploitation of resources and capabilities, but also by competitive weaknesses that may tamper the business' competitive efforts. Building on the RBV literature, different analytical approaches have been proposed to analyze competitive weaknesses, including resource weaknesses, competitive disadvantage and strategic liabilities (Arend, 2004; Powell, 2001; Sirmon et al., 2010; West and De Castro, 2001). These studies emphasize various factors that explain the negative effect of competitive weaknesses on performance. First, competitive weaknesses increase the business' vulnerability to market conditions or competitors' actions, which is detrimental to sales and, ultimately, performance (West and De Castro, 2001). Second, businesses with clear competitive weaknesses have a lower possibility to pursue business opportunities (Sirmon et 
al., 2010). For example, lack of access to certain resources and capabilities—e.g., financial resources, human capital, networks—-negatively affect the business' capacity to engage in new strategic actions linked to technology regeneration or internationalization.

\subsection{The configuration of the system of competencies: Connecting competitive pillars}

From an organizational perspective, a business can be conceptualized as a network of routines that govern all processes as well as the often complex relationships between resources and capabilities (Grant, 1991, p. 122). The effective exploitation of resources and capabilities is not only conditioned by their mere availability, but also by the ability of the business to orchestrate its resources and capabilities (Miller and Whitney, 1999). Therefore, the simple analysis of the relationship between competitive strengths, weaknesses and performance may yield partial conclusions with regard to the RBV theory. Prior work has mostly used the net-effect logic to analyze the connections between resources and capabilities. The net-effect logic focuses on the role of dominant competitive forces (strengths or weaknesses). This approach defines competitiveness as a function of available competencies and, regardless the overall competitiveness level, the configuration of competencies (strengths or weaknesses) determines business outcomes (Ray et al., 2004; Sirmon et al., 2010).

At the business level, resources and capabilities are the central cornerstones upon which businesses can formulate potentially successful strategies (Grant, 1991). By acknowledging the interconnectedness of resources and capabilities, we propose an alternative approach to competitiveness based on the configuration of the business' system of competencies. We argue that the potentially positive value of a focal competency is a function of both its availability and the configuration of the system of competencies. In the context of this paper, configuration refers to a multidimensional property that varies across firms, and is defined as the degree to which the business' resources and capabilities are amalgamated and connected by a single theme (Miller, 1996). Building on the configuration theory developed by Miller (1986; 1996), the elements of a system cannot fully be understood in isolation, so the analysis of the system as a whole is inevitable. While it is easy to copy a single element, competitive advantage lies “....in the power of the orchestrating theme and the degree of complementarity it engenders among the elements” (Miller and Whitney, 1999, p. 13).

This argument is in line with RBV postulates that organizations are a bundle of interconnected resources and capabilities (Grant, 1991; Powell, 2001), and that accurate competitiveness analyses should take into account competitive strengths and weaknesses, as well as the configuration of business competencies. For example, technology and knowledge 
are highly interconnected resources in professional service businesses, such as financial or knowledge-based consultancy firms. The use of obsolete technology may negatively affect the exploitation of human capital resources (skilled employees will likely struggle with internal procedures in their day-to-day routines). In this example, and regardless of the business' competitiveness level, poor technology implementation limits the full exploitation of employees' knowledge and deteriorates both competitiveness and business operations. On contrary, the contribution of human capital to business competitiveness will increase as the firm harmonizes other resources—i.e., technology—or develop competitive strengths.

Figure 1 illustrates the performance implications of the different configurations of competencies. The harmonization of competencies favors the exploitation of the resourcecapability combinations, and performance will result from the value of their competencies. For low-competitive firms, a harmonized system of competencies may lack critical resources and capabilities that limit their capacity to implement value-adding strategies (Sirmon et al., 2011). Although the weak harmonization of competencies, these firms are in a better competitive position than businesses with various competitive weaknesses. For highcompetitive firms, a harmonized set of competencies constitutes a source of competitive advantage and their effective orchestration contributes to develop strategic actions seeking to differentiate from competitors and, consequently, stimulate performance (Sirmon et al., 2010). In this case, strong harmonization will yield high performance levels.

--- Insert Figure 1 about here ---

Although their increased vulnerability to competitors’ actions, businesses with a harmonized set of competencies are in a better position to exploit their resources and capabilities; therefore, their performance results are conditioned by the value of their competencies. Therefore, we hypothesize:

H1 (a): Among low-competitive businesses, a harmonization strategy leads to greater performance compared to businesses with competitive weaknesses

H1 (b): Among high-competitive businesses, a harmonization strategy constitutes a source of competitive advantage that yields to superior performance results comparable to that generated by businesses with competitive strengths

In sum, competitiveness is a multidimensional construct which, to a large extent, results from the interaction between resources and capabilities. This is the focus on our study. This 
study seeks to contribute a deeper understanding of how businesses capitalize on their resources and capabilities. Building on the configuration theory, the following section describes the competitiveness index used to evaluate the sampled businesses.

\section{The competitiveness index}

Organizations have different strengths and weaknesses, in terms of resources and capabilities, and their identification is critical because the key to a business' success or its future development lies in its ability to create or develop distinctive competencies (Teece et al., 1997). Prior studies underline a number of firm-specific sources of competitiveness; however, previous attempts to measure competitiveness rely on either individual variables or the estimation of aggregate metrics in which the analyzed components individually contribute to competitiveness (Aral and Weill, 2007; Douglas and Ryman, 2003; Fernhaber and Patel, 2012; O’Cass and Weerawardena, 2010). These measures capture the statistical association between the analyzed variables. However, competitiveness analyses based on aggregate metrics may fail to capture the potential connections between resources and capabilities. Based on these arguments and following the theory in section 2.3 we propose that:

Competitiveness is the mutually dependent bundle of ten pillars-human capital, product, domestic market, networks, technology, decision making, strategy, marketing, internationalization, and online presence-that allow a firm to effectively compete with other firms and serve customers with valued goods/services.

The competitive pillars included in our definition of competitiveness match RBV postulates (see e.g., Barney, 1991; Man et al., 2002; Peteraf, 1993; Wernerfelt, 1984). The composition of the ten pillars helps to capture the configuration of the analyzed resources and capabilities. Static components include the most important aspects of the competence or existing practices. Dynamic elements refer to changes in the static components over the threeyear period preceding the application of the survey. These are typically the innovation- or entrepreneurship-related variables. For example, in the human capital pillar the static elements are the level of human capital (education), the potential problems with employees, and the sophistication of the compensation system. Dynamism and rarity are captured by the share of employees in training programs and the uniqueness of human capital, respectively.

Various attempts made way for developing diverse competitiveness measures (see section 2). By interlocking the RBV with configuration theory postulates, and in line with Lafuente et al. (2019) we follow a four-step procedure to compute competitiveness. 
To estimate the competitiveness index $(C I)$, we first normalize in the $[0,1]$ range all variables included in the analysis $(j=1, \ldots J)$ as:

$x_{i, j}^{*}=\frac{x_{i, j}}{\max \left(x_{j}\right)}, \quad j=1, \ldots, J$ and $i=1, \ldots, N$

In equation (1) $x_{i, j}^{*}$ is the normalized value for the $j$ th variable obtained for the ith business, while $x_{i, j}$ is the original value of the focal variable. The selected benchmarks $\left(\max \left(x_{j}\right)\right)$ are, for each variable $(j)$, the highest score. Data normalization procedures aim to scale variables with different magnitudes down to the same level, and this approach has been used in previous work dealing with index building methodologies (see, e.g., Acs et al., 2014; Lafuente et al., 2019; Michailidou et al., 2015). We use the distance normalization approach because, contrary to the min-max technique, this approach preserves the observed relative difference among the analyzed businesses.

In the second step, we separate the normalized variables $(J)$ into 10 vectors $(\mathbf{v})$ which correspond to the analyzed competitiveness pillars $\left(\mathbf{v}=\left(v_{1}, \ldots, v_{J}\right) \in R_{+}^{J}\right)$. The pillar scores $\left(p_{i, v}\right)$ are computed for each firm $(i=1, \ldots, N)$ and the number of variables used to estimate each pillar $(k=1, \ldots, K)$ may vary across pillars. The pillar scores are the average value of the variables included in each pillar (v). Additionally, pillar values are normalized in the $[0,1]$ range to ease their interpretation. The normalized competitiveness pillars are computed as:

$$
\begin{aligned}
p_{i, v} & =\frac{\sum_{k=i}^{K} x_{i, v}^{*}}{K}, \quad v=1, \ldots, 10 \text { and } k=1, \ldots, K \\
p_{i, v}^{*} & =\frac{p_{i, v}}{\max \left(p_{v}\right)},
\end{aligned}
$$

Note that the pillar values (equation (2b)) widely vary, which may blur their interpretation. Businesses do not employ productive resources at the same intensity and the efforts needed to enhance competitiveness can be different across businesses and across pillars, regardless of whether these efforts improve pillars with higher or lower values. Given the managerial approach of this study, the additional resources necessary to achieve the same marginal improvement of average pillar scores should be the same. Thus, and to enhance estimation accuracy, in the third step we equalize the marginal effect of the competitiveness 
pillars $\left(p_{i, v}\right)$, and estimate the strength and direction of the adjustment for each pillar by finding the root of the following expression for $\delta$ :

$$
\begin{aligned}
& y_{i, v}=p_{i, v}^{*} \delta \\
& \sum_{i=1}^{N} p_{i, v}^{* \delta}-N \bar{y}_{v}=0
\end{aligned}
$$

In equations (3a) and (3b) $\delta$ represents the "strength of adjustment" for the vth pillar, that is, the $\delta$-th moment of $p_{i, v}^{*}$ is exactly the pillar's average value $\left(\bar{y}_{v}\right)$. Equation (3b) draws a decreasing and convex function, and the solution for $\delta$ is obtained by implementing the Newton-Raphson method with an initial guess of zero (Atkinson, 2008). After estimating $\delta$, computations are straightforward. From equations (3a) and (3b) note that if:

$\bar{p}_{v}^{*}<\bar{y}_{v} \quad \delta<1$

$\bar{p}_{v}^{*}=\bar{y}_{v} \quad \delta=1$

$\bar{p}_{v}^{*}>\bar{y}_{v} \quad \delta>1$

In this way, through the procedure presented in equations (3a) and (3b) we obtain the strength (and direction) of the adjustment $(\delta)$ for the analyzed pillars. This approach has been used in prior work assessing different multidimensional phenomena using index numbers (see, e.g., Acs et al., 2014; Lafuente et al., 2019).

Finally, in the fourth step we use the results from equations (1)-(3b) to calculate the competitiveness index $(C I)$ for each firm as the sum of the ten pillars $\left(p_{i, v}^{*}\right)$ as follows:

$$
C I_{i}=\sum_{v=1}^{10} p_{i, v}^{*}
$$

The approach to competitiveness used in this study is a valuable managerial control tool which not only unveils business weaknesses and their effect on competitiveness, but also captures the multiple relationships that exist among the analyzed competitiveness pillars.

\section{Empirical application: Data and variables used to build the competitiveness index}

\subsection{Data}

The empirical illustration uses a unique primary dataset drawn from a research project on competitiveness of Hungarian enterprises supported by the European Union (TÁMOP 4.2.2 A-11/1/KONV-2012-0058). Data were collected specifically for the purpose of this study and 
the process was entirely supervised by a team of the Faculty of Business and Economics at the University of Pécs (Hungary). The selection process of the surveyed firms was two folded.

First, we selected a random sample of firms from the OPTEN company database that includes all businesses registered in the Hungarian Business Registry. From this dataset nearly 9,500 firms were selected according to size, industry and geographic quotas. In the context of this study, top managers are a relevant respondent group. After an initial telephone call for approval, in the second step a face-to-face interview was carried out to one of the owners (only if he/she is in top management team) in the case of firms smaller than 20 employees, while for businesses larger than 20 employees a top executive-irrespective of whether he/she has ownership rights or not-was interviewed. The data collection process was achieved through self-administrated, structured interviews where managers were asked to answer essentially close questions. The survey was conducted by a professional market investigation firm, and the data was collected between March and June 2013. The questionnaire was subject to a pre-test to correct potentially misleading or confusing questions.

A total number of 662 surveys were obtained (response rate: 6.98\%). Yet, in the interest of following a rigorous methodology, only observations for which a complete dataset of the analyzed variables could be constructed were included. Thus, we excluded 37 businesses with incomplete data. This yielded a final sample of 625 businesses. The average business has 26 employees (median: 7 employees) with 15 years of market experience. The analysis of the industry configuration of the final sample reveals that $32 \%$ of firms operate in manufacturing sectors, while the proportion of retailing and professional services businesses is $40 \%$ and $28 \%$, respectively. We tested non-response bias for early and late respondents in terms of business size (employees), business age and sales across the analyzed industry sectors. We found no significant differences.

Additionally, data on sales and assets were obtained from official publicly available sources of the Hungarian Ministry of Justice. ${ }^{1}$ Based on the unique identification code available from the questionnaire, information was collected for the sampled businesses during the period 2010-2013. Data available allow at computing a performance variable linked to employment growth between 2010 and 2013. This information was used to carry out the regression analysis linking competitiveness to employment growth. Details on this analysis and its results are presented in section 5.2.

\footnotetext{
${ }^{1}$ Data are available at http://www.e-cegjegyzek.hu/index.html
} 


\subsection{Variables used to estimate the competitiveness pillars}

To compute the competitiveness index (equation (4)) we employed two groups of variables. The first set of variables deals with different resources and capabilities, while the second group of variables captures changes in these variables during 2010-2013. Respondents were asked along a five-point scale to value the individual importance of the analyzed resources and capabilities, and these variables are only valuable if deemed so by respondents (Priem and Butler, 2001). In the proposed Likert-type scale a value of “1” designates a low relevant variable, while a value of “ 4 ” represents a highly relevant variable. The value of " 0 ” indicates that the focal variable has no strategic value whatsoever (Douglas and Ryman, 2003), and the remaining points of the scale ensure the uniform evaluation of the variables' importance. Also, the division of the positive scale values (from 1 to 4 ) allows a sufficient degree of differentiation in the valuation of the analyzed variables (Lederer et al., 2013).

It should be kept in mind that, to ease readability for respondents, the coding of some variables was modified as a result of the nature of the questions. In the case of the human capital pillar, numerical values were used to codify the educational attainment of employees (number and share of employees with higher education degree) and the proportion of employees actively participating in training programs. Similarly, the weight of new product in the business' sales is introduced in the product pillar, while the number of cooperation and innovation agreements was used in the computation of the networks pillar. The strategy pillar includes the number of economic activities (NACE codes) as a proxy variable for the diversification strategy of the business. Finally, the proportion of sales in foreign markets was included in the internationalization pillar.

Therefore, from our questionnaire it is possible to obtain information for 46 variables related to the ten competitiveness pillars (competencies) analyzed in this study. The description of the variables used to build the competitiveness pillars are presented in the Appendix (Table A1). The competitiveness pillars are computed, for each business, by solving equations (1)-(3b), and these values are introduced in equation (4) to estimate the competitiveness index. Descriptive statistics for the normalized pillar values and the competitiveness index (equation (4)) are presented in Table 1.

--- Insert Table 1 about here ---

In line with the literature presented in section 2.2, one would be tempted to question whether the selected variables (Table A1 in the Appendix) measure the corresponding 
competencies, and whether the analyzed pillars accurately represent the competitiveness construct. To further corroborate the appropriateness of the variable selection process, a robustness check was carried out based on the estimation of a principal component factor analysis that evaluates how well the 46 observed variables reflect the 10 pillars that form the competitiveness index. Results in Table A2 of the Appendix reveal that the reliability test (Cronbach's alpha) for the 10 competitiveness pillars ranges between 0.6451 (marketing) and 0.8623 (online presence). This result confirms that the constructs extracted from the factor models are internally consistent across the analyzed variables to measure the competencies under evaluation (Nunnally and Bernstein 1994). A second factor model corroborates that the selected competitive pillars efficiently measure the competitiveness construct (Table A2).

\section{Results}

The section presents the empirical results. We first show the potential impact of changes in competitive pillars over competitiveness. This analysis (section 5.1) represents an ideal illustration of how the proposed competitiveness index can be used for managerial purposes. To test the study hypotheses, the second stage analysis (section 5.2) presents the results of the regression models relating the proposed competitiveness index to employment growth.

\subsection{Competitiveness assessment}

This section evaluates the responsiveness of the competitiveness index to improvements in different pillars. More concretely, we analyze the effects on competitiveness of employing additional recourses to improve the weakest pillar, the two weakest pillars and strong pillars. This competitiveness analysis is of crucial importance for businesses. Keep in mind that, for simplicity, underlying this analysis are the assumptions that the cost of additional resources is the same for all pillars, and that additional resources are equally available for all businesses.

To illustrate the functioning of the competitiveness index, Table 2 presents two cases extracted from the dataset in which available additional resources-equivalent to 0.10 index points - are employed to improve 1) the weakest (bottleneck) pillar, 2) the strongest pillar, and 3) the two weakest pillars by a combined amount of 0.10 index points.

The first example refers to a low-competitive business with a clear weak pillar. In this case, an increase in 0.10 index points in the weakest (bottleneck) pillar (i.e., online presence) enhances the business' competitiveness score by $11.33 \%$ ( 0.20 points) from 1.81 to 2.01 . Note that if the organization uses the resources to improve the strongest pillar (human capital), competitiveness only increases 4.20\%. Additionally, if the business adopts a harmonization 
strategy and employs the additional resources to improve the two weakest pillars (online presence and networks), the reported improvement in the competitiveness index is $8.77 \%$, a value which is lower than that reported for the bottleneck-improvement strategy. These results suggest that competitiveness enhancing actions of poor performing businesses should be more aligned with actions that improve the weakest (bottleneck) pillar. The proposed managerial tool may prove itself useful in that it can contribute to improve managers' decision-making and to efficiently allocate resources that seek to enhance competitiveness.

--- Insert Table 2 about here ---

The second example in Table 2 presents a high-performing firm with a more balanced competitiveness system. Results indicate that a harmonization strategy linked to improving the two weakest pillars (human capital and domestic market) produces the greatest competitiveness improvement (1.70\%), relative to the increase resulting from improving the weakest pillar (1.54\%). The results show that, for high-performing firms, managers should value harmonization strategies that seek to improve the business' competitiveness level.

\subsection{The relationship between the configuration of the competitiveness system and performance}

The analysis in section 5.1 shows how businesses may improve their competitiveness level by investing in internal resources and capabilities. In addition to possessing these ingredients, the RBV theory emphasizes the exploitation of valuable competencies based on rare and hard to imitate resources and capabilities to confer competitive advantage (Barney, 1991). Underlying this argument is the assumption that businesses orchestrate their competencies in such a way that their performance metrics are maximized (Mahoney and Pandain, 1992; Peteraf, 1993). In the context of this study, this implies that performance variations can be explained by differences in both competitiveness and the configuration of the competitiveness system. Thus, the analysis presented in this section tests the relationship between competitiveness, the configuration of the system of competencies and performance by estimating the following regression model:

\section{Employment}

growth $_{i}=\beta_{0}+\beta_{1}$ Competitiveness $_{i}+\beta_{2}$ Configuration of competitiveness system $_{i}$

$+\beta_{12}$ Competitiveness $\times$ Configuration of competitiveness system $i$

$$
+\beta_{3} \text { Control variables }_{i}+\varepsilon_{i}
$$


In equation (5) $\boldsymbol{\beta}$ is the vector of coefficients for the independent variables and $\varepsilon_{i}$ is the normally distributed error term. Concerning the dependent variable, business growth is a critical outcome for SMEs and it can be measured in many ways, including sales, assets or employment (Davidsson et al., 2002; Lafuente and Rabetino, 2011; Nason and Wiklund, 2018; Wiklund et al., 2009). Also, Davidsson et al. (2006, p. 8) conclude that growth metrics based on employment show the highest correlation with alternative growth indicators. Following Davidsson et al. (2002), employment growth is measured as $\left(\right.$ Employment $_{i, t}-$ Employment $\left._{i, t-c}\right) /\left[\left(\right.\right.$ Employment $_{i, t}+$ Employment $\left.\left._{i, t-c}\right) / 2\right]$ to obtain an asymptotically normally distributed variable between 2010 (c) and $2013(t)$.

To test the proposed hypotheses we used a set of dummy variables to identify businesses showing competitive strengths, competitive weaknesses, or a harmonized competitiveness system. To ensure estimation accuracy we first obtained, for each business, the skewness of the competitive pillars. The skewness statistic indicates how symmetrically distributed is a set of observed values (Greene, 2003, p. 879). The analysis of the role of the configuration of the competitive pillars on performance is of interest in this study, and this variable contributes to reveal the configuration of competitive pillars. Regardless of their competitiveness score, businesses were grouped according to the configuration of their competitiveness system as follows. A symmetrical distribution $(-1 \leq$ skewness $\leq 1)$ indicates that competitive pillars are harmonized. A left skewed result (negative skew: <-1) points to a concentration of values on the right tail of the distribution, which points to the presence of bottleneck pillars (competitive weaknesses). A right skewed distribution (positive skewness: $>1$ ) suggests that pillars are highly concentrated in the left tail of the distribution of competencies, that is, few highperforming pillars shape competitiveness (competitive strengths). This grouping approach allows for a strong degree of differentiation, in terms of the configuration of the competitiveness system. Also, a reasonable number of businesses fall into each of the categories (bottleneck = 225 firms, harmonization $=316$, competitive strengths $=84$ ).

To further explore the relationship between the configuration of the competitiveness system and performance, we employed a median split along the competitiveness score of the sampled firms, according to the configuration of their system of competitiveness. By introducing interaction terms between the competitiveness level (below- and above-the median) and the dummy variables linked to the configuration of the competitiveness system we identified businesses represented in the four areas identified in Figure 1. 
We control for size, age, industry and location. As in Davidsson et al. (2006) and Lafuente and Rabetino (2011), we use the number of employees in the base year (in our case, 2010) to measure size, while business age is expressed in years. The variables size and age were logged to reduce skewness. A set of dummy variables were used to control for industry effects (manufacturing, retailing and professional services). Finally, following the NUTS-2 criterion, we included a set of dummy variables accounting for the location of the business were introduced in the models. Regression models were estimated via OLS, and descriptive statistics for the study variables are presented in Table 3.

The regression models relating competitiveness and performance are depicted in Table 4. To address the threat of collinearity, we computed the average variance inflation factor (VIF) for all variables. In all models, the average and highest VIF values do not exceed the generally accepted rule of thumb of 10 for assessing collinearity. The results for this diagnostic test do not raise collinearity concerns. Specification 1 in Table 4 is the baseline model testing the relationship between the competitiveness index and growth. Models 2 to 4 show the results for the effect on performance of each of the variables related to the configuration of the competitiveness system. Models 5 and 6 evaluate the performance effects of the competitiveness score and the configuration of the competitiveness system (the reference category is the group of businesses with bottleneck pillars).

\section{--- Insert Tables 3 and 4 about here ---}

The findings show that the competitiveness index significantly explains performance differences among the sampled businesses. For example, from Model 1 we note that, ceteris paribus, the estimated change in employment growth resulting from a one unit increase in the competitiveness index is 9.61 percentage points ( $t$-value $=5.03$ and $p$-value $<0.001)$. Results in Model 2 indicate that, regardless the competitiveness level, employment growth raises 21.10 percentage points in businesses with a set of competitive strengths, relative to the rest of businesses, while for businesses with competitive weaknesses employment growth falls 15.60 percentage points relative to the rest of businesses (Model 4). Additionally, for firms with solid competitive strengths employment growth is 27.39 percentage points higher than the value reported for businesses with bottleneck competitive pillars (Model 5).

The results for the test of Hypotheses 1(a) and 1(b) are presented in Model 6. From the results in Model 6, Figure 2 displays the estimated average employment growth according to 
the SMEs' competitiveness level (below and above the median) and to the configuration of their competitiveness system (bottleneck pillars, harmonization and competitive strengths).

--- Insert Figure 2 about here ---

Hypothesis 1(a) proposes that, among low-competitive businesses, a harmonization strategy leads to greater performance results compared to businesses with bottleneck competencies. Results estimated from Table 4 and presented in Figure 2 do not support this hypothesis. The estimated average growth rate in low-competitive businesses with a harmonized competitiveness system (1.57\%) is not significantly different from that computed for businesses with clear bottlenecks pillars $(-2.33 \%)(t$-test $=0.69$, $p$-value $=0.49)$. Also, the estimated average growth rate in businesses with competitive strengths (6.77\%) is significantly greater than that reported for businesses both with a harmonized competitiveness system $(t$-test $=3.15, p$-value $<0.01)$ and with bottlenecks pillars $(t$-test $=2.69, p$-value $<$ 0.01). This result is in line with prior work emphasizing that businesses with a clear set of competitive strengths enjoy a greater capacity to create or develop a sustainable competitive advantage, which translates in superior performance (Crook et al., 2008; Sirmon et al., 2010).

Hypothesis 1(b) states that, among high-competitive businesses, a harmonization strategy constitutes a source of competitive advantage that yields to superior performance results comparable to that generated by businesses with competitive strengths. Results support this hypothesis. The estimated growth rate of businesses with clear competitive strengths (9.93\%) is not significantly different than that estimated for firms with a harmonized strategy $(6.27 \%)$ ( $t$-test $=1.46, p$-value $<0.14)$. Also, high-competitive firms with bottleneck pillars show the lowest employment growth rate (3.56\%), and this result is significantly lower than that reported by firms with a harmonized competitiveness system (and $t$-test $=1.71, p$-value $<$ 0.088 ) and by firms with competitive strengths ( $t$-test $=2.23, p$-value $<0.027)$ (Figure 2).

The results confirm that competitive weaknesses limit SMEs' ability to react to market conditions and expand business operations (Arend, 2004; Douglas and Ryman, 2003). Also, the result for the group of high-competitive SMEs suggests that businesses with a harmonized system of competencies achieve performance results comparable to those resulting from the exploitation of competitive strengths (Sirmon et al., 2010; Lafuente et al., 2019).

Finally, we conducted two robustness checks to ensure estimation accuracy. First, we tested the potential non-linear effect of competitiveness on performance. Results (available on request) for the linear and squared term of the competitiveness index are not significant. 
Second, we tested for the potential moderating effect of size in the relationship between competitiveness and performance. In unreported results, available on request, the interaction term between size and competitiveness is not significant, while the sign and significance level of the competitiveness coefficient remain unchanged.

\section{Discussion}

Building on the RBV and the configuration theories, the systemic competitiveness analysis used in this study reveals the importance of identifying the configuration of businesses' competitive pillars. The view that SMEs' competitiveness only differs in an additive level due to differences in resource availability, and that all that SMEs need to do for improving their competitiveness level is to replicate strategies observed in other (more competitive) peers, is overly simplistic. Instead of conducting a traditional study of correlations connecting different resources and capabilities to competitiveness, our analysis relates competitiveness and the configuration of the competitiveness system to performance. In this sense, we present robust estimations that contribute to delineate the competitiveness level of Hungarian SMEs as well as to unveil the effects of the configuration of their competitiveness system on employment growth.

Additionally, our results show important extensions to two of the most central tenets of the strategic management field. On the one hand, the first finding relates to the negative effect of competitive weaknesses on competitiveness and performance. We found a negative effect of weak (bottleneck) competitive pillars on performance, and significant competitiveness improvements in businesses that carry out specific investments targeting weak (bottleneck) competitive pillars. This way, businesses with clear bottleneck competitive pillars could benefit by directing profits toward the elimination of weaknesses, thus reducing their vulnerability to competitors and market conditions. The role of competitive weaknesses has been largely sidelined in prior research (Crook et al., 2008; Newbert, 2007). However, these results suggest that competitive weaknesses are also important to performance, and that they should be considered in future research based on the RBV framework.

Finally, the results show that SMEs with a more balanced system of resources and capabilities benefit more from a harmonization strategy that seeks to improve various competencies, regardless their competitiveness level. This result is important for at least two reasons. First, the result runs against the net-effect logic (Arend, 2004; Ray et al., 2004) and gives support to the argument that investment strategies focused on the maximization of competitive strengths is not always the most efficient pathway to enhance competitiveness. 
Second, this finding underlines the relevance of having a clear understanding of the sources of competitive advantage. Instead of focusing on competitive strengths, this study suggests that the focus should expand by considering the configuration of the business' competitive system into the analysis. Therefore, the competitiveness index can be a useful tool that may provide critical information to improve strategic decision-making seeking to enhance competitiveness and, ultimately, performance (Nason and Wiklund, 2018; Wiklund et al., 2009).

\section{Concluding remarks, implications and future research directions}

\subsection{Concluding remarks}

In this study we have adopted a system dynamics approach to compute a managerial tool for evaluating business competitiveness. Building on insights from the RBV theory and the configuration theory, competitiveness is conceptualized as a multidimensional construct that results from the mutually dependent associations between resources and capabilities (Barney, 2001; Prahalad and Hamel, 1990). Instead of analyzing the individual contribution of certain resources and capabilities, we examine SMEs' competitiveness from a systemic perspective. We show the usefulness and the informative power of the competitiveness index by showing how the adoption of strategies oriented to improve resources or capabilities contributes to enhance the competitiveness level of SMEs. Thus, our analysis shows how businesses can optimize the allocation of additional resources that seek to increase their competitiveness.

Overall, we found that the configuration of the business' competitive system-in terms of resources and capabilities_conditions the generally positive impact of competitiveness enhancing actions linked to the acquisition or development of resources and capabilities.

\subsection{Implications}

The findings presented in this study have important implications for scholars, practitioners as well as policy makers.

Academic implications.-From an academic perspective, prior work on the RBV has addressed the contribution of resources and capabilities to competitiveness through the individual analysis of relevant variables or factor analysis models (e.g., Douglas and Ryman, 2003; Fernhaber and Patel, 2012). Despite the rigorous efforts, aggregate competitiveness measures obscure the performance implications of distinct resources and capabilities. The results reveal that, when evaluated as a monolith, the positive effect of competitiveness on performance is readily evident, when in fact different resources and capabilities may have conflicting performance implications. That is, the configuration of competitive pillars has a 
decisive role to play within competitiveness-enhancing strategies: low-competitive firms benefit more from investments in weak pillars, while a harmonization strategy seems more appropriate for high-competitive firms with a more balanced competitiveness system. This is an important contribution of this study.

The computed competitiveness score matches RBV's postulates that emphasize the complexity of the associations between resources and capabilities with the need to accurately measure competitiveness from a holistic perspective. By adopting a system dynamics approach that accounts for the boundaries of the firm's competitiveness system, this study contributes to the literature on the determinants of firm competitiveness (e.g., Newbert, 2008; Sirmon et al., 2011). Also, our focus on SMEs in an emerging economy contributes to expand the stock of research on business competitiveness in developed and developing economies (e.g., Alonso and Leiva, 2019; Hansen et al., 2013; Hult et al., 2007; Lafuente et al., 2019).

Implications for strategy makers.-For the strategy practitioner the competitiveness index may help to underscore the importance of giving the multidimensionality of competitiveness a central role in strategic planning for optimizing strategic investments. The competitiveness measure has managerial implications not only due to the benchmarking for monitoring business activities, but also because the index constitutes a valuable tool for managerial control. We suggest that managers need to turn their attention to the development of both quantitative-including aspects dealing with operational and financial aspects—and qualitative metrics - including aspects related to strategy, product and online presence-when evaluating both competitiveness and the effectiveness of competitiveness-enhancing actions.

Resources and capabilities are heterogeneously distributed across businesses, which conditions the ability of managers to create a resource-based competitive advantage. Without a proper analysis of the system of competencies, businesses replicating competitivenessenhancing actions adopted by industry peers would not necessarily achieve the same outcomes. The results suggest that businesses need a balance between competitive pillars. Overemphasis on few competitive pillars does not guarantee long-term competitiveness. Businesses seeking to enhance competitiveness should first evaluate their strengths and weaknesses. In this sense, the competitiveness index may represent the instrument to carry out this business-level analysis, and provide managers with valuable information that help direct future actions and investments to improve the business' competitive position.

Policy implications.-From a policy perspective, the analysis presented in this study offers valuable insights that cannot be reflected by simply using ratio analysis or aggregate competitiveness metrics. The results highlighting the relevance of the configuration of 
competitive pillars would tend to suggest a clear policy recommendation: tailor-made SME support policies based on the characteristics of the targeted firms would be more effective than canonical policy actions that uniformly stimulate specific resources or capabilities. Also, the results of this research may usefully be made more central to inform policy makers on what specific policy actions are potentially conducive to more competitive SME sectors.

For example, data made available by the Small Business Act (SBA) of the EU indicates that, compared to their EU counterparts, Hungarian SMEs are less economically impactful, in terms of the value added injected to the economy (Table 5). It has been argued that the lower weight of Hungarian SMEs in the economy is a consequence of their low innovative performance and digital capabilities (Makó et al., 2012; Muraközy et al., 2018), human capital deficiencies (Richbell et al., 2010), and inefficient networking (Mandják et al., 2012).

\section{--- Insert Table 5 about here ---}

The heterogeneity of Hungarian SMEs reported in these studies at the aggregate level is in line with the business-level findings presented in this study. The Hungarian government has mobilized resources through specific policies—e.g., the 'supplier development program' endowed with a 6.5 million Euro budget to promote active collaborations between large and small businesses, and the 'Áldomás network' of small food producers-in order to improve the competitiveness of Hungarian SMEs. Although these policies help to improve specific resources or capabilities (e.g., human capital, technology) they do not take into account firmspecific heterogeneity, and this may condition the output of such policies.

We do not propose to disregard investments in these input-enhancing policies. Put briefly, we propose that policy makers need detailed information about what competitive pillars (and what configuration of competitive pillars) are more relevant at industry level in order to design economically meaningful sector-specific policies that help improve the competitiveness of SMEs. In a related manner, an additional implication of our analysis is that optimal SME support actions should not be based on policy isomorphism, that is, a convergence strategy based on the replication of what other, often more developed peers, do. That is, optimal SME support policy relies less on the mere deployment of more resources and instead involves direct encouragement to the development of industry-specific actions that target those competitive pillars that should be improved, according to the analysis of the configuration of the system of competencies. 


\subsection{Future research lines}

The results presented in this study are open to further verification. First, the data do not permit the direct analysis of the effect of improvements in resources or capabilities on competitiveness. We present various interpretations of how resource-enhancing actions impact competitiveness; however, we do not evaluate how firms internalize these investments into their operations, nor do we assess the trade-off between the cost of such investments and their effects on competitiveness. Further research on this issue would be valuable. For example, future work should evaluate whether the process to amalgamate new resources with existing ones condition competitiveness improvements within firms. This suggests the need for more detailed data dealing with the effects of specific investments on competitiveness. Second, future research should corroborate the robustness of the competitiveness index in other industries, and in public firms which are exposed to external market pressures and whose managers tend to prioritize short-term profits over long-run strategic objectives (Fisman et al., 2014). Third, while we grouped 46 variables in ten competitive pillars, it is necessary to further validate the competitiveness index and test the relevance of other competencies. From a strategic perspective, specifically designed future research can address this point by evaluating whether specific factors related to the entrepreneur(s) and to the market where the business operates—e.g., high-tech sectors or stock markets—have a differentiated effect on competitiveness.

\section{References}

Acs, Z., Autio, E., and Szerb, L. (2014), “National systems of entrepreneurship: Measurement issues and policy implications”, Research Policy, Vol. 43 No. 3, pp. 476-494.

Alonso, S. and Leiva, J.C. (2019), “Business competitiveness in Costa Rica: a multidimensional approach”, TEC Empresarial, in press.

Aral, S. and Weill, P. (2007), "IT assets, organizational capabilities, and firm performance: How resource allocations and organizational differences explain performance variation”, Organization Science, Vol. 18 No. 5, pp. 763-780.

Arend, R.J. (2004), “The definition of strategic liabilities, and their impact on firm performance”, Journal of Management Studies, Vol. 41 No. 6, pp. 1003-1027.

Atkinson, K.E. (2008), An introduction to numerical analysis, John Wiley \& Sons, New York.

Barney, J.B. (1991), “Firm resources and sustained competitive advantage”, Journal of Management, Vol. 17 No. 1, pp. 99-120. 
Barney, J.B. (2001), “Resource-based theories of competitive advantage: A ten-year retrospective on the resource-based view”, Journal of Management, Vol. 27 No. 6, pp. 643-650.

Barney, J.B. and Mackey, T.B. (2005), “Testing resource-based theory”, in Ketchen, D.J. and Bergh D.D., Research Methodology in Strategy and Management, Elsevier, Greenwich, CT, pp. 1-13.

Belderbos, R. and Sleuwaegen, L. (2005), “Competitive Drivers and International Plant Configuration Strategies: A Product-Level Test”, Strategic Management Journal, Vol. 26 No. 6, pp. 577-593.

Crook, T.R., Ketchen, D.J., Combs, J.G., and Todd, S.Y. (2008), “Strategic resources and performance: A meta-analysis”, Strategic Management Journal, Vol. 29 No. 11, pp. 11411154.

Davidsson, P., Delmar, F., and Wiklund, J. (2006), Entrepreneurship and the Growth of Firms, Elgar, Cheltelham (UK).

Davidsson, P., Kirchhoff, B., Hatemi, J.A., and Gustavsson, H. (2002), "Empirical analysis of employment growth factors using Swedish data”, Journal of Small Business Management, Vol. 40 No. 4, pp. 332-349.

Douglas, T.J. and Ryman, J.A. (2003), “Understanding competitive advantage in the general hospital industry: evaluating strategic competencies”, Strategic Management Journal, Vol. 24 No. 4, pp. 333-347.

European Commission (2018), “2018 SBA Fact Sheet: Hungary”, Small Business Act (SBA), European Commission Directorate-General for Internal Market, Industry, Entrepreneurship and SMEs (DG GROW). Available at https://ec.europa.eu/growth/smes/business-friendlyenvironment/small-business-act

Fernhaber, S. and Patel, P. (2012), “How Do Young Firms Manage Product Portfolio Complexity? The Role of Absorptive Capacity and Ambidexterity”, Strategic Management Journal, Vol. 33 No. 13, pp. 1516-1539.

Fisman, R.J., Khurana, R., Rhodes-Kropf, M., and Yim, S. (2014), “Governance and CEO turnover: Do something or do the right thing?”, Management Science, Vol. 60 No. 2, pp. 319-337.

Grant, R.M. (1991), “The resource-based theory of competitive advantage: implications for strategy formulation”, California Management Review, Vol. 33 No. 3, pp. 114-135.

Greene, W. (2003), Econometric Analysis, Prentice Hall, Upper Saddle River (NJ). 
Hansen, J.M., McDonald, R.E. and Mitchell, R.K. (2013), “Competence resource specialization, causal ambiguity, and the creation and decay of competitiveness: the role of marketing strategy in new product performance and shareholder value”, Journal of the Academy of Marketing Science, Vol. 41 No. 3, pp. 300-319.

Hult, G.T.M., Ketchen, D., and Arrfelt, M. (2007), “Strategic supply chain management: Improving performance through a culture of competitiveness and knowledge development”, Strategic Management Journal, Vol. 28 No. 10, pp. 1035-1052.

Julien, P.A. and Ramangalahy, C. (2003), “Competitive strategy and performance of exporting SMEs: An empirical investigation of the impact of their export information search and competencies”, Entrepreneurship Theory \& Practice, Vol. 27 No. 3, pp. 227245.

Ketchen, D.J. Jr, Hult, G.T.M., and Slater, S.F. (2007), “Toward greater understanding of market orientation and resource-based view”, Strategic Management Journal, Vol. 28 No. 9, pp. 961-964.

Kingsley, G. and Malecki, E.J. (2004), "Networking for competitiveness”, Small Business Economics, Vol. 23 No. 1, pp. 71-84.

Lafuente, E., Leiva, J.C., Moreno, J., and Szerb, L. (2019), “A non-parametric analysis of competitiveness efficiency: The relevance of firm size and the configuration of competitive pillars”, BRQ Business Research Quarterly, in press, doi: 10.1016/j.brq.2019.02.002

Lafuente, E. and Rabetino R. (2011), "Human Capital and Growth in Romanian Small Firms”, Journal of Small Business and Enterprise Development, Vol. 18 No. 1, pp. 74-96.

Lederer, M., Schott, P., Huber, S., and Kurz, M. (2013), “Strategic Business Process Analysis: A Procedure Model to Align Business Strategy with Business Process Analysis Methods”, S-BPM ONE-Running Processes, Springer, Berlin Heidelberg, pp. 247-263.

Mahoney, J.T. and Pandain, J.R. (1992), "The resource-based view within the conversation of strategic management”, Strategic Management Journal, Vol. 13 No. 5, pp. 363-380.

Makó, C., Miklós, I., and Csizmadia, P. (2012), “Declining Innovation Performance of the Hungarian Economy: Special Focus on Organizational Innovation. The Example of the European Community Innovation Survey (CIS)”, Journal of Entrepreneurship, Management and Innovation, Vol. 8 No. 1, pp. 116-137.

Man, T.W.Y., Lau, T., and Chan, K.F. (2002), “The competitiveness of small and medium enterprises: A conceptualization with focus on entrepreneurial competencies”, Journal of Business Venturing, Vol. 17 No. 2, pp. 123-142. 
Mandják, T., Wimmer, Á. and Juhász, P. (2012), “A hálózati pozíció és a versenyképesség kapcsolata”, Vezetéstudomány, Vol. 42 No. 2, pp. 14-23.

Michailidou, A.V., Vlachokostas, C., and Moussiopoulos, N. (2015), “A methodology to assess the overall environmental pressure attributed to tourism areas: A combined approach for typical all-sized hotels in Chalkidiki, Greece”, Ecological Indicators, Vol. 50, pp. 108-119.

Miller, D. (1986), “Configurations of Strategy and Structure: Towards a Synthesis”, Strategic Management Journal, Vol. 7 No. 3, pp. 233-249.

Miller, D. (1996), “Configurations revisited”, Strategic Management Journal, Vol. 17 No. 7, pp. 505-512.

Miller, D. and Whitney, J.O. (1999), “Beyond Strategy: Configuration as a Pillar of Competitive Advantage”, Business Horizons, Vol. May-June, pp. 5-17.

Muraközy, B., Bisztray, M. and Reizer, B. (2018), "Productivity differences in Hungary and mechanisms of TFP growth slowdown”, Luxembourg: Publications Office of the European Union (IV+190 p.).

Nason, R.S. and Wiklund, J. (2018), “An assessment of resource-based theorizing on firm growth and suggestions for the future”, Journal of Management, Vol. 44 No. 1, pp. 32-60.

Newbert, S. (2007), "Empirical research on the Resource-based view of the firm: An assessment and suggestions for future research”, Strategic Management Journal, Vol. 28 No. 2, pp. 121-146.

Newbert, S. (2008), "Value, rareness, competitive advantage, and performance: a conceptual-level empirical investigation of the resource-based view of the firm”, Strategic Management Journal, Vol. 29 No. 7, pp. 745-768.

Nunnally, J.C. and Bernstein, I.H. (1994), Psychometric Theory, McGraw-Hill, New York.

O’Cass, A. and Weerawardena, J. (2010), “The effects of perceived industry competitive intensity and marketing-related capabilities: Drivers of superior brand performance”, Industrial Marketing Management, Vol. 39 No. 4, pp. 571-581.

Peteraf, M.A. (1993), “The cornerstones of competitive advantage: A resource-based view”, Strategic Management Journal, Vol. 14 No. 3, pp. 179-191.

Porter, M.E. (1998), “Clusters and the new economics of competition”, Harvard Business Review, Vol. 76 No. 6, pp. 77-90.

Powell, T.C. (2001), “Competitive advantage: logical and philosophical considerations”, Strategic Management Journal, Vol. 22 No. 9, pp. 875-888. 
Prahalad, C.K. and Hamel, G. (1990), "The Core Competence of the Corporation”, Harvard Business Review, Vol. 68 No. May-June, pp. 79-91.

Priem, R. and Butler, J. (2001), “Is the resource-based 'view’ a useful perspective for strategic management research?”, Academy of Management Review, Vol. 26 No. 1, pp. 2240.

Ray, G., Barney, J.B., and Muhanna, W.A. (2004), “Capabilities, business processes, and competitive advantage: choosing the dependent variable in empirical tests of the resourcebased view”, Strategic Management Journal, Vol. 25 No. 1, pp. 23-37.

Richbell, S., Szerb, L. and Vitai, Z. (2010), “HRM in the Hungarian SME sector”, Employee Relations, Vol. 32 No. 3, pp. 262-280.

Siggelkow, N. (2011), “Firms as Systems of Interdependent Choices”, Journal of Management Studies, Vol. 48 No. 5, pp. 1126-1140.

Sirmon, D.G. and Hitt, M.A. (2009), “Contingencies within dynamic managerial capabilities: Interdependent effects of resource investment and deployment on firm performance”, Strategic Management Journal, Vol. 30 No. 13, pp. 1375-1394.

Sirmon, D.G., Hitt, M.A., Arregle, J.L., and Campbell, J.T. (2010), “The dynamic interplay of capability strengths and weaknesses: investigating the bases of temporary competitive advantage”, Strategic Management Journal, Vol. 31 No. 13, pp. 1386-1409.

Sirmon, D.G., Hitt, M.A., Ireland, R.D., and Gilbert, B.A. (2011), "Resource orchestration to create competitive advantage breadth, depth, and life cycle effects”, Journal of Management, Vol. 37 No. 5, pp. 1390-1412.

Tarabusi, E.C. and Guarini, G. (2013), “An unbalance adjustment method for development indicators”, Social Indicators Research, Vol. 112 No. 1, pp. 19-45.

Teece, D., Pisano, G., and Shuen, A, (1997), “Dynamic capabilities and strategic management”, Strategic Management Journal, Vol. 18 No. 7, pp. 509-533.

Tippins, M.J. and Sohi, R.S. (2003), “IT competency and firm performance: is organizational learning a missing link?”, Strategic Management Journal, Vol. 24 No. 8, pp. 745-761.

Wernerfelt, B. (1984), “A Resource-Based View of the Firm”, Strategic Management Journal, Vol. 5 No. 2, pp. 171-180.

West, G.P. and De Castro, J. (2001), “The Achilles heel of firm strategy: resource weakness and distinctive inadequacies”, Journal of Management Studies, Vol. 38 No. 3, pp. 417-442.

Wiklund, J., Patzelt, H., and Shepherd, D.A. (2009), "Building an integrative model of small business growth”, Small Business Economics, Vol. 32 No. 4, pp. 351-374. 


\section{List of Figures}

Figure 1. The relationship between the configuration of competitive pillars and performance

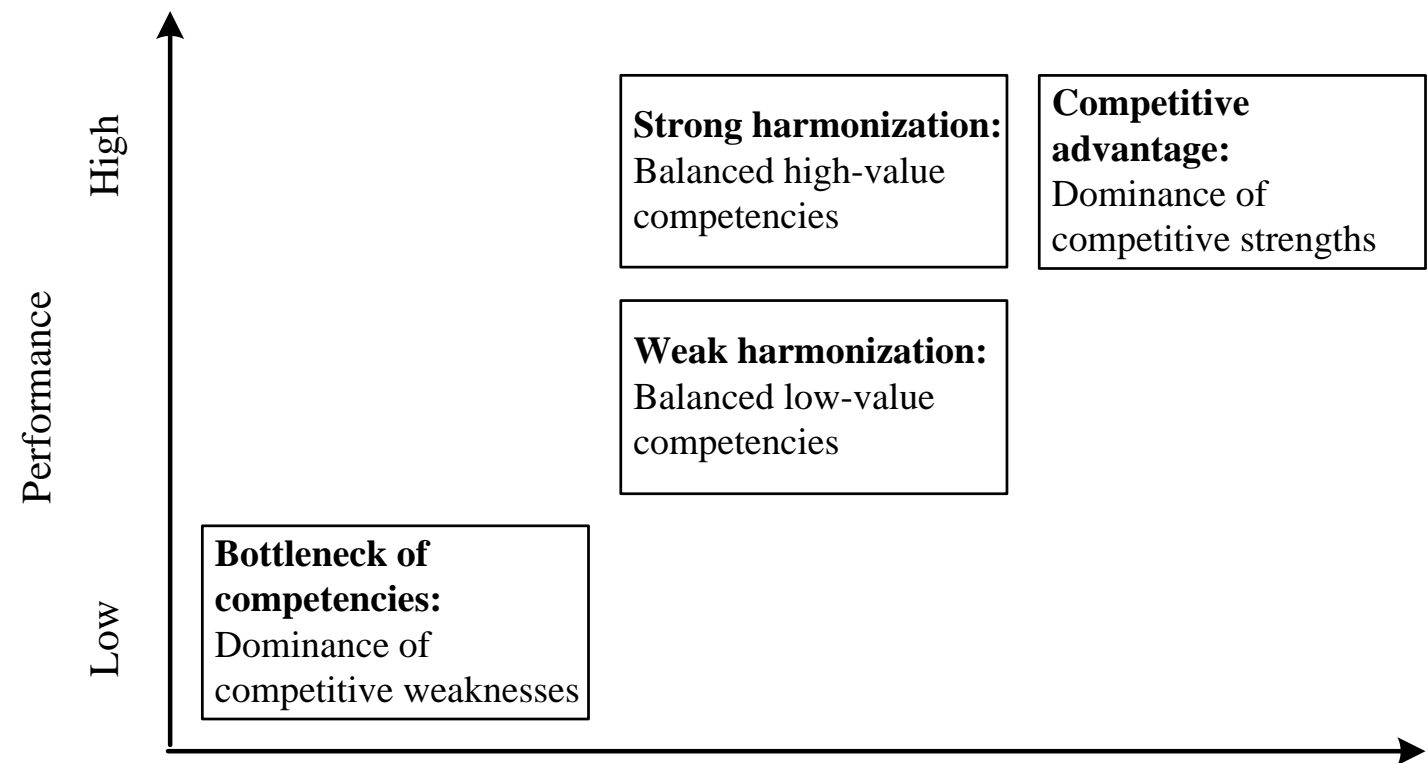

Configuration of the competitiveness system

Figure 2. Response surface of competitiveness and the configuration of competitive pillars

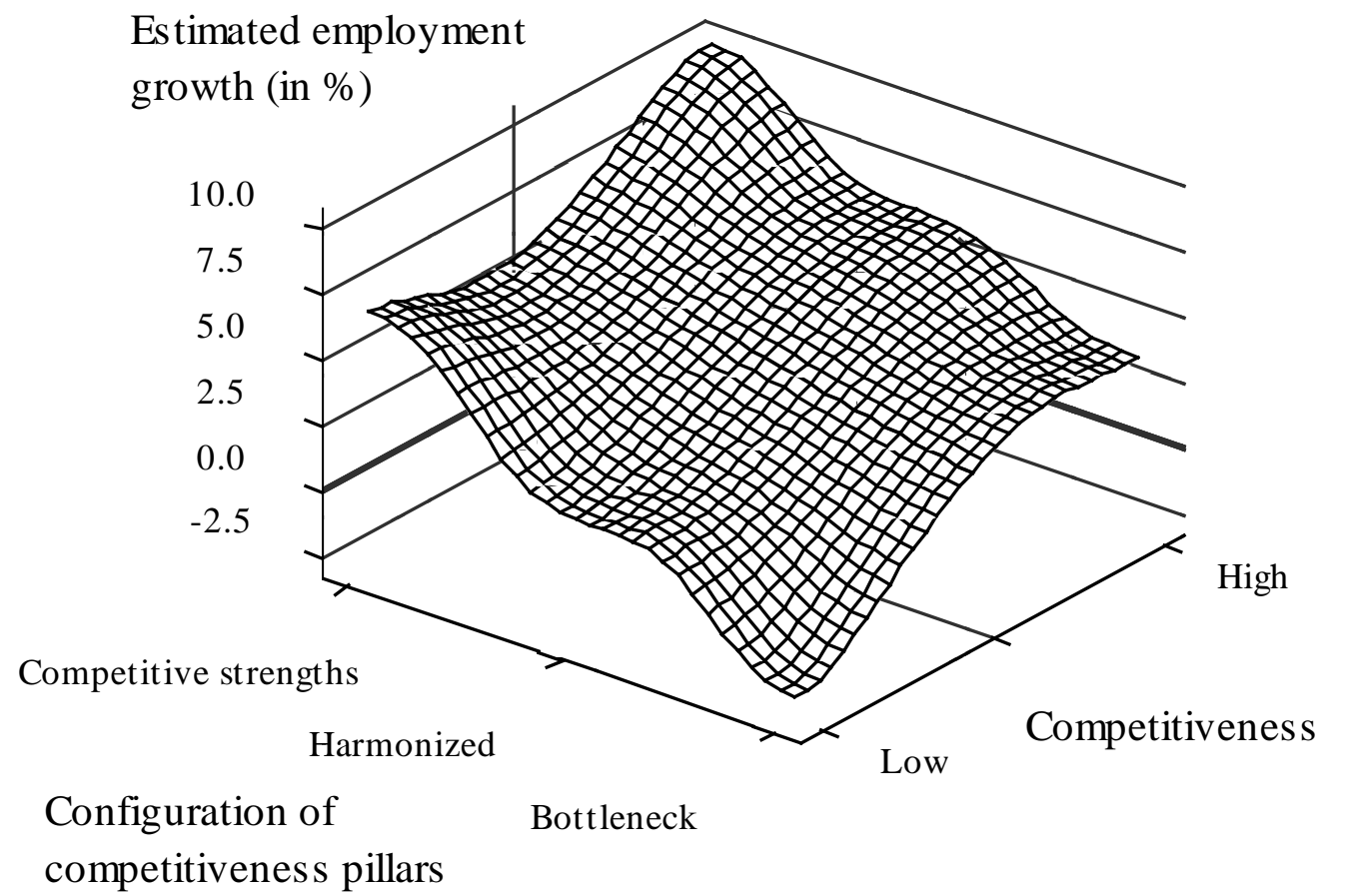

Source: Authors’ elaboration 


\section{List of Tables}

Table 1. Competitiveness: Descriptive statistics for the selected competitive pillars

\begin{tabular}{lcccc}
\hline & Mean & Std. dev. & Q1 & Q3 \\
\hline Competitiveness index $(C I)$ & 3.8859 & 1.3438 & 2.8783 & 4.8244 \\
Competitiveness pillars & & & & \\
Human capital & 0.3941 & 0.1446 & 0.2784 & 0.4863 \\
Product & 0.3926 & 0.1553 & 0.3062 & 0.4898 \\
Domestic market & 0.3889 & 0.1584 & 0.2715 & 0.4951 \\
Networks & 0.3838 & 0.1982 & 0.2590 & 0.5234 \\
Technology & 0.3918 & 0.1566 & 0.2784 & 0.4930 \\
Decision making & 0.3804 & 0.1961 & 0.2263 & 0.5271 \\
Strategy & 0.3817 & 0.1735 & 0.2693 & 0.4947 \\
Marketing & 0.3926 & 0.1572 & 0.2787 & 0.4838 \\
Internationalization & 0.3837 & 0.1926 & 0.2385 & 0.5269 \\
Online presence & 0.3962 & 0.2881 & 0.0200 & 0.6423 \\
\hline
\end{tabular}

Number of observations: 625 . 
Table 2. Competitiveness index: Business-level results

\begin{tabular}{|c|c|c|c|c|c|c|c|c|}
\hline & \multicolumn{4}{|c|}{ Example 1: poor performing business with a clear bottleneck } & \multicolumn{4}{|c|}{ Example 2: high performing business } \\
\hline & \multicolumn{5}{|c|}{ Improvement strategies } & \multicolumn{3}{|c|}{ Improvement strategies } \\
\hline & $\begin{array}{l}\text { Normalized } \\
\text { pillar values }\end{array}$ & (1) & $(2)$ & (3) & $\begin{array}{l}\text { Normalized } \\
\text { pillar values }\end{array}$ & $(1)$ & $(2)$ & (3) \\
\hline Human capital & 0.2404 & 0.2566 & 0.3162 & 0.2495 & 0.6191 & 0.7156 & 0.6191 & 0.6689 \\
\hline Product & 0.2085 & 0.2214 & 0.2085 & 0.2161 & 0.6508 & 0.6512 & 0.6508 & 0.6513 \\
\hline Domestic market & 0.1930 & 0.2042 & 0.1930 & 0.1997 & 0.6343 & 0.6344 & 0.6343 & 0.6839 \\
\hline Networks & 0.1382 & 0.1437 & 0.1382 & 0.1882 & 0.7268 & 0.7283 & 0.7268 & 0.7298 \\
\hline Technology & 0.2169 & 0.2306 & 0.2169 & 0.2248 & 0.7041 & 0.7053 & 0.7041 & 0.7063 \\
\hline Decision making & 0.2030 & 0.2154 & 0.2030 & 0.2103 & 0.6996 & 0.7007 & 0.6996 & 0.7017 \\
\hline Strategy & 0.1934 & 0.2047 & 0.1934 & 0.2002 & 0.6701 & 0.6707 & 0.6701 & 0.6712 \\
\hline Marketing & 0.2338 & 0.2494 & 0.2338 & 0.2426 & 0.7083 & 0.7095 & 0.7083 & 0.7107 \\
\hline Internationalization & 0.1416 & 0.1474 & 0.1416 & 0.1457 & 0.6586 & 0.6591 & 0.6586 & 0.6594 \\
\hline Online presence & 0.0369 & 0.1369 & 0.0369 & 0.0869 & 0.7937 & 0.7963 & 0.8723 & 0.7989 \\
\hline Competitiveness index & 1.8057 & 2.0103 & 1.8815 & 1.9640 & 6.8652 & 6.9711 & 6.9438 & 6.9820 \\
\hline $\begin{array}{l}\text { Improvement } \\
\text { (index points) }\end{array}$ & & 0.2046 & 0.0758 & 0.1583 & & 0.1058 & 0.0785 & 0.1168 \\
\hline Improvement (\%) & & $11.33 \%$ & $4.20 \%$ & $8.77 \%$ & & $1.54 \%$ & $1.14 \%$ & $1.70 \%$ \\
\hline
\end{tabular}

The normalized pillar values are obtained from equations (3a) and (3b). Results in the table refer to the case in which the organization employs 0.10 index-points to enhance its competitiveness (equation (4)) by adopting one of the following strategies: 1) improvement of the weakest pillar, 2) improvement of the strongest pillar (below 1), and 3) improvement of the two weakest pillars (harmonization approach). 
Table 3. Regression analysis: Descriptive statistics for the selected variables

\begin{tabular}{lcc}
\hline & Mean value & Std. dev. \\
\hline Performance variable & & \\
Employment growth & 0.0721 & 0.6259 \\
Configuration of the competitiveness system & & \\
Core competencies (competitive strengths) & 0.1344 & 0.3414 \\
Harmonized & 0.5056 & 0.5004 \\
Competitive weaknesses & 0.3600 & 0.4804 \\
Control variables & & \\
Business size in 2010 (employees) & 25.98 & 77.65 \\
Business size (average employees) & 26.01 & 75.39 \\
Business age (years) & 14.59 & 6.70 \\
Manufacturing & 0.3200 & 0.4668 \\
Retailing & 0.3968 & 0.4896 \\
Professional services sectors & 0.2832 & 0.4509 \\
Budapest & 0.1888 & 0.3917 \\
Central Hungary & 0.0848 & 0.2788 \\
Central Transdanubia & 0.0736 & 0.2613 \\
Western Transdanubia & 0.0704 & 0.2560 \\
Southern Transdanubia & 0.2960 & 0.4569 \\
Northern Hungary & 0.0702 & 0.2587 \\
North Great Plain & 0.0926 & 0.2904 \\
South Great Plain & 0.1216 & 0.3271 \\
\hline
\end{tabular}

Number of observations: 625. 
Table 4. Regression analysis: The relationship between competitiveness and employment growth

\begin{tabular}{|c|c|c|c|c|c|c|}
\hline & Model 1 & Model 2 & Model 3 & Model 4 & Model 5 & Model 6 \\
\hline Competitiveness index & $\begin{array}{c}0.0961 * * * \\
(0.0191)\end{array}$ & $\begin{array}{c}0.0940 * * * \\
(0.0208)\end{array}$ & $\begin{array}{c}0.0957 * * * \\
(0.0211)\end{array}$ & $\begin{array}{c}0.0928 * * * \\
(0.0207)\end{array}$ & & \\
\hline $\begin{array}{l}\text { High competitiveness } \\
\text { (above the median) }\end{array}$ & & & & & $\begin{array}{c}0.2189 * * * \\
(0.0501)\end{array}$ & $\begin{array}{l}0.1077 * \\
(0.0648)\end{array}$ \\
\hline Competitive strengths & & $\begin{array}{c}0.2110 * * \\
(0.0871)\end{array}$ & & & $\begin{array}{c}0.2739 * * * \\
(0.0917)\end{array}$ & $\begin{array}{l}0.1653 * * \\
(0.0843)\end{array}$ \\
\hline Harmonized & & & $\begin{array}{c}0.0416 \\
(0.0466)\end{array}$ & & $\begin{array}{c}0.1223 * * \\
(0.0477)\end{array}$ & $\begin{array}{c}0.0420 \\
(0.0522)\end{array}$ \\
\hline Bottleneck & & & & $\begin{array}{c}-0.1560 * * * \\
\quad(0.0479)\end{array}$ & & \\
\hline $\begin{array}{l}\text { High competitiveness X } \\
\text { Competitive strengths } \\
\text { High competitiveness X } \\
\text { Harmonized }\end{array}$ & & & & & & $\begin{array}{l}0.2094 * \\
(0.1184) \\
0.1643 * \\
(0.0915)\end{array}$ \\
\hline Control variables & YES & YES & YES & YES & YES & YES \\
\hline Intercept & $\begin{array}{c}0.5494 * * * \\
(0.1388)\end{array}$ & $\begin{array}{c}0.5310 * * * \\
(0.1375)\end{array}$ & $\begin{array}{c}0.5304 * * * \\
(0.1458)\end{array}$ & $\begin{array}{c}0.6208 * * * \\
(0.1419)\end{array}$ & $\begin{array}{c}0.7092 * * * \\
(0.1296)\end{array}$ & $\begin{array}{c}0.7516 * * * \\
(0.1263)\end{array}$ \\
\hline F-test & $9.35 * * *$ & $8.47 * * *$ & $8.76 * * *$ & $8.64 * * *$ & $7.21 * * *$ & $6.52 * * *$ \\
\hline Adjusted R2 & 0.1384 & 0.1502 & 0.1380 & 0.1508 & 0.1521 & 0.1538 \\
\hline Root MSE & 0.5810 & 0.5770 & 0.5811 & 0.5768 & 0.5763 & 0.5757 \\
\hline Average VIF (min-max) & $\begin{array}{c}1.40 \\
(1.18-1.87)\end{array}$ & $\begin{array}{c}1.37 \\
(1.02-1.87)\end{array}$ & $\begin{array}{c}1.37 \\
(1.04-1.87)\end{array}$ & $\begin{array}{c}1.38 \\
(1.05-1.87)\end{array}$ & $\begin{array}{c}1.38 \\
(1.12-1.86)\end{array}$ & $\begin{array}{c}1.92 \\
(1.18-3.75)\end{array}$ \\
\hline Observations & 625 & 625 & 625 & 625 & 625 & 625 \\
\hline
\end{tabular}

Robust standard errors are presented in brackets. All model specifications include size (ln employees in 2010), business age (ln years), industry dummies (manufacturing is the reference category) and territorial dummies (Budapest is the reference category) as control variables. *, **, *** indicate significance at the $10 \%, 5 \%$ and $1 \%$, respectively. 
Table 5. SMEs in Hungary and Europe (EU-28): Basic figures for 2017

\begin{tabular}{|l|r|r|r|r|r|r|}
\hline Size class & \multicolumn{2}{|c|}{$\%$ enterprises } & \multicolumn{2}{c|}{$\%$ of total employment } & \multicolumn{2}{c|}{$\begin{array}{c}\text { contribution to total } \\
\text { value added }\end{array}$} \\
\hline & Hungary & \multicolumn{1}{|c|}{ EU-28 } & Hungary & \multicolumn{1}{c|}{ EU-28 } & \multicolumn{1}{c|}{ Hungary } & \multicolumn{1}{c|}{ EU-28 } \\
\hline Micro & $94.0 \%$ & $93.1 \%$ & $33.4 \%$ & $29.4 \%$ & $18.0 \%$ & $20.7 \%$ \\
\hline Small & $5.0 \%$ & $5.8 \%$ & $19.0 \%$ & $20.0 \%$ & $17.5 \%$ & $17.8 \%$ \\
\hline Medium-sized & $0.8 \%$ & $0.9 \%$ & $16.5 \%$ & $17.0 \%$ & $18.3 \%$ & $18.3 \%$ \\
\hline SMEs & $\mathbf{9 9 . 8} \%$ & $\mathbf{9 9 . 8} \%$ & $\mathbf{6 8 . 8} \%$ & $\mathbf{6 6 . 4} \%$ & $\mathbf{5 3 . 7} \%$ & $\mathbf{5 6 . 8} \%$ \\
\hline Large & $0.2 \%$ & $0.2 \%$ & $31.2 \%$ & $33.6 \%$ & $46.3 \%$ & $43.2 \%$ \\
\hline Total & $100.0 \%$ & $100.0 \%$ & $100.0 \%$ & $100.0 \%$ & $100.0 \%$ & $100.0 \%$ \\
\hline
\end{tabular}

Source: 2018 SBA Fact Sheet Hungary (p. 2) (https://ec.europa.eu/growth/smes/business-friendlyenvironment/performance-review_en) 


\section{Appendix}

Table A1. Description of the variables used to build the pillars that form the competitiveness index

\begin{tabular}{|c|c|}
\hline Competitiveness pillar & Variables included in the pillar \\
\hline 1. Human capital & $\begin{array}{l}\text { The number and share of employees with higher education degree } \\
\text { The problems with employees } \\
\text { The share of employees participating in training programs } \\
\text { The sophistication of compensation systems } \\
\text { The uniqueness of human capital }\end{array}$ \\
\hline 2. Product & $\begin{array}{l}\text { Product innovation } \\
\text { Activities/effort concerning the introduction of new or amended product } \\
\text { The share of new product in sales } \\
\text { The uniqueness of firm's product and continuous innovation }\end{array}$ \\
\hline 3. Domestic market & $\begin{array}{l}\text { The geographic scope of selling in Hungary } \\
\text { The level of firm's competition in the market } \\
\text { The expected growth of the target market in five years } \\
\text { The intensity of competition } \\
\text { Quick response to costumers' demand }\end{array}$ \\
\hline 4. Networks & $\begin{array}{l}\text { The number of economic cooperation and innovation agreements } \\
\text { The time of networking as compared to the establishment of the firm } \\
\text { The reliance to outside help in business development } \\
\text { Uniqueness of networking relationship }\end{array}$ \\
\hline 5. Technology & $\begin{array}{l}\text { The level of firm's technology in Hungary } \\
\text { The age of available technology used by the firm and technological } \\
\text { innovation } \\
\text { Environmental investment and quality assurance } \\
\text { The level of application of ICT tools } \\
\text { Uniqueness of applied technology, possession of license or know-how, } \\
\text { product management and quality assurance }\end{array}$ \\
\hline 6. Decision making & $\begin{array}{l}\text { The application of the different sources of information } \\
\text { The application of financial analyses in the business } \\
\text { Information sharing } \\
\text { Consultation in decision making } \\
\text { Administrative routines/operations knowledge sharing of the business } \\
\text { organization }\end{array}$ \\
\hline 7. Competitive strategy & $\begin{array}{l}\text { The direction of strategy (defensive, proactive) } \\
\text { Growth strategy based on the number of business units } \\
\text { The leader's entrepreneurial traits } \\
\text { The uniqueness of firm' proactive strategy }\end{array}$ \\
\hline
\end{tabular}


Table A1. Continued

\begin{tabular}{|c|c|}
\hline Competitiveness pillar & Variables included in the pillar \\
\hline \multirow{6}{*}{ 8. Marketing } & The product \\
\hline & The pricing of the main product \\
\hline & Sophistication of distribution channels \\
\hline & Applied marketing and communication tools \\
\hline & Marketing innovation \\
\hline & The uniqueness of marketing methods \\
\hline \multirow{4}{*}{ 9. Internationalization } & The significance of foreign buyers \\
\hline & The share of export in sales \\
\hline & Language capabilities at business level \\
\hline & The uniqueness of location \\
\hline \multirow{4}{*}{ 10. Online presence } & Webpage technical characteristics \\
\hline & Webpage offered services \\
\hline & Webpage content \\
\hline & Online marketing applications \\
\hline
\end{tabular}

Table A2. Factor analysis: Summary of measurement results

\begin{tabular}{lccccc}
\hline & Variables & $\begin{array}{l}\text { Cronbach's } \\
\text { alpha }\end{array}$ & $\begin{array}{l}\text { Kaiser-Meyer- } \\
\text { Olkin (KMO) test }\end{array}$ & Eigenvalue & $\begin{array}{l}\text { Variance } \\
\text { explained (\%) }\end{array}$ \\
\hline $\begin{array}{l}\text { Competitiveness index } \\
\text { Competitiveness pillars: }\end{array}$ & 10 & 0.8513 & 0.8984 & 4.3141 & 43.14 \\
Human capital & 5 & 0.7332 & 0.6146 & 1.5458 & 30.92 \\
Product & 4 & 0.6928 & 0.5899 & 1.6734 & 41.84 \\
Domestic market & 5 & 0.7061 & 0.5258 & 1.5784 & 31.57 \\
Networks & 4 & 0.6777 & 0.5945 & 1.8105 & 45.26 \\
Technology & 5 & 0.7297 & 0.6751 & 1.7283 & 34.57 \\
Decision making & 5 & 0.7012 & 0.7201 & 2.3121 & 46.24 \\
Strategy & 4 & 0.7114 & 0.5005 & 1.3488 & 33.72 \\
Marketing & 6 & 0.6451 & 0.6866 & 1.8823 & 31.37 \\
Internationalization & 4 & 0.7042 & 0.5365 & 2.0063 & 50.16 \\
Online presence & 4 & 0.8623 & 0.7901 & 2.9434 & 73.58 \\
\hline
\end{tabular}

Number of observations: 625. 